\title{
Thermal Performance of Solar Hot Water Systems Using a Flat Plate Collector of Accelerated Risers
}

\author{
KE Amori* and NS Jabouri \\ Department of Mechanical Engineering, Nahrain University, University of Baghdad, Baghdad, Iraq
}

Received 3 May 2010; accepted 27 September 2010

\begin{abstract}
This study focuses on a comparison of the performance of two similar locally-fabricated solar water heaters. One of the collectors features a new design for accelerated absorber; its risers are made of converging ducts whose exit area is half that of the entrance. The other collector is a conventional absorber, with risers of the same cross sectional area along its length. Each collector is the primary part of an indirect thermosyphon circulation solar hot water system. Both collectors face south with a fixed tilt angle of $33.3^{\circ}$ from the horizontal. A side-by-side experiment was conducted on the two solar water heaters from January to April of 2009 for different water withdrawal profiles, continuous, interrupted and no load, as well as for horizontal and vertical storage tank orientations. Two types of storage tanks were investigated, those with two concentric cylinders, and those with helically-coiled tubes in the cylinder. Results show that a considerable enhancement of thermal performance (approximately 60\%) of absorbed heat (useful gain) at solar noon was obtained for the new design, in comparison with the conventional type. The instantaneous efficiency was $31.5 \%$ for the accelerated absorbed flat plate at solar noon, while that of conventional absorber was (16.5\%). The longitudinal water temperature variations in the risers of accelerated absorber were larger than that of the conventional absorber. The stratification in the storage tank was significantly improved for the solar hot water system, with the new absorber design in which the maximum temperature measured was $50{ }^{\circ} \mathrm{C}$ (vertical storage tank), while that for conventional absorber was $37^{\circ} \mathrm{C}$. The stratification obtained for a coiled tube in a cylinder storage tank indicated a good thermal performance with less space requirements. Also, the circulation rate in the accelerated absorber was higher when it was connected to a coiled tube than when it was connected to the concentric cylinders.
\end{abstract}

Keywords: Solar, Accelerated flat plate collector, Storage tank, Coiled tube, Stratification

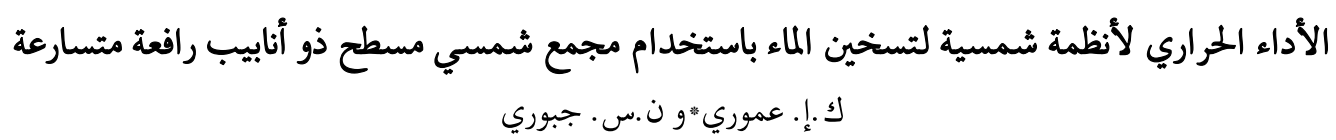

الملخص: تركز هذه الدراسة على مقارنة أداء منظومتين شمسيتين متماثلتين مصنوعتين محليا تستخدمان لتسخين الماء. أحد هذين المجمعين ذو

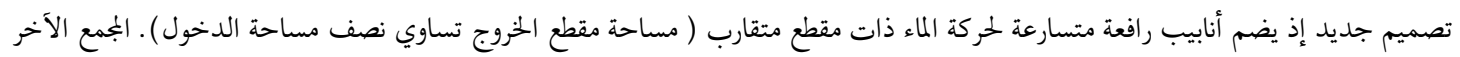

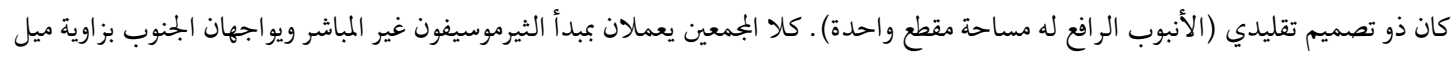

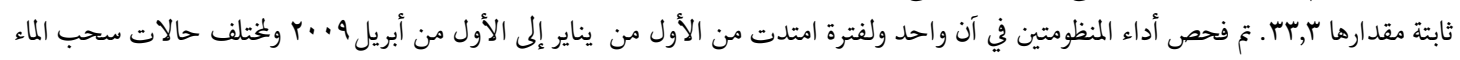

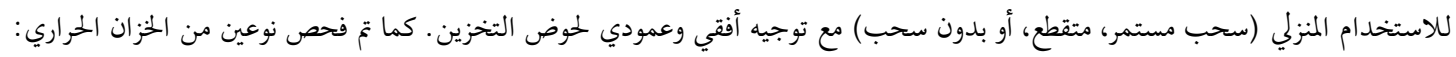

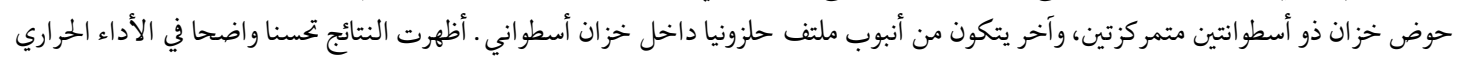

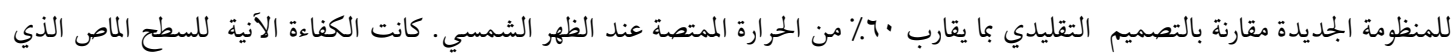

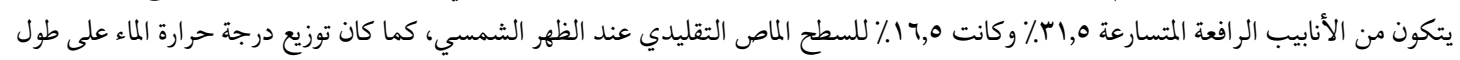

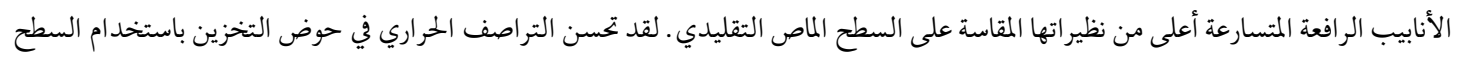

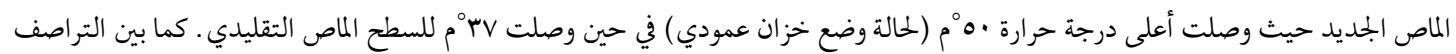

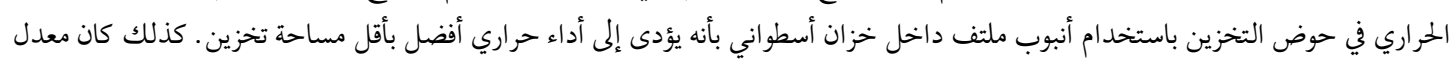

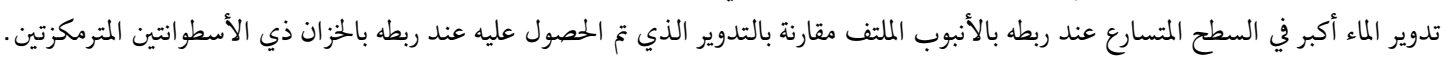

الكلمات الدالة: شمسي، مجمع شمسي، مسطح متسارع، حوض التخزين، أنبوب ملتف، تراصف حراري

$\overline{\text { *Corresponding author's e-mail:drkarimaa@yahoo.com }}$ 


\section{Introduction}

Solar hot water systems function as heat exchangers. They receive solar radiant energy and transfer it to the flowing fluid. The performance of solar systems varies as the design variables change, so it is therefore necessary to identify the parameters affecting this design and the operational variables.

Keltt et al. (1984) studied through experimentation the thermal performance of submerged coil heat exchangers for single wall coil and double wall coil for different tank sizes namely (300 L and $450 \mathrm{~L}$ ) for different load flow rates. Khalifa (1999) investigated a thermosyphon domestic hot water system to show the important variables that affect the performance of the solar system such as the temperature variation along the absorber fins, tubes and in the flow direction as well as the thermosyphonic mass flow rate. The design of an efficient storage tank heat exchanger has been investigated by (Shokouhmand et al. 2008) with different coil pitches and curvature ratios. An enhancement in the heat transfer rate is obtained due to the centrifugal force due to the curvature of the tube, resulting in the secondary flow development. The objective of the present work is to compare experimentally thermal performance of a locally-made new solar flat plate collector (named here as accelerated solar collector) to a flat plate collector of straight risers the conventional type hot water system for a different water withdrawal pattern. Additionally, the study will show the stratification in the storage tank. In order to carry out a fair comparison, the collectors are made as identically possible.

\section{Theory}

Thermal analysis has covered in many solar thermal engineering texts (Duffie, Beckman 1974; Lunde 1980). Therefore, only equations which describe the thermal performance of the system will be described in this paper.

\section{Actual Collector And Supply Useful Energy Gain}

For the collector closed- loop cycle, the hourly useful energy gain can be calculated by:

$$
Q_{\text {coll }}=m_{\text {coll }} C_{p}\left(T_{\text {out }}-T_{\text {in }}\right)
$$

The heat obtained by the water withdrawal can be calculated as:

$$
Q_{\text {sup }}=m_{\text {sup }} C_{p}\left(T_{18}-T_{20}\right)
$$

Where $\mathrm{Q}_{\text {coll }}$ heat is transferred in $\mathrm{W}, \mathrm{m}^{\bullet}$ mass flow rate in $\mathrm{kg} / \mathrm{s}, \mathrm{C}_{\mathrm{p}}$ water specific heat in $\mathrm{J} / \mathrm{kg} . \mathrm{K}$, $\mathrm{T}$ is the measured temperature at the collector inlet or outlet $\left({ }^{\circ} \mathrm{C}\right)$, and $\mathrm{T}_{20}$ and $\mathrm{T}_{18}$ are supply water temperatures at inlet and outlet from the storage tank, as shown in Fig. (1b) and Fig. (3).

The useful energy enhancement is calculated as:

$\%$ enhance. $=\frac{(\text { useful energy })_{\text {acc. }}-(\text { useful energy })_{\text {conv. }}}{(\text { useful energy })_{\text {conv. }}}$

The collector instantaneous efficiency can be determined according to:

$$
\eta_{\text {coll }}=\mathrm{Q}_{\text {coll }} /\left(\mathrm{A}_{\text {coll }} * \mathrm{IG}\right)
$$

IG is the global solar radiation on tilted collector at $33.3^{\circ}$ from horizontal calculated from that measured on a horizontal surface.

\section{Experimental Setup}

Two identical solar water heaters are manufactured in this experiment; one is supplied with flat plate collectors of accelerated absorber, the other is supplied with flat plate collectors of conventional absorber. Figure 1 shows the configuration of solar water heater tested when its storage tank is composed of two concentric cylinders, and when it is a helical coiled tube in cylindrical shell.

\subsection{Accelerated Flat Plate Solar Collector}

A flat plate collector with an accelerator plate consists of nine equally-spaced parallel converging rectangular cross-sectional area copper risers (Fig. 2) with an inlet hydraulic diameter of $2 \mathrm{~cm}$. The inlet dimensions are $20 \times 20 \mathrm{~mm}$, and the outlet hydraulic diameter $13.3 \mathrm{~mm}$, while the outlet dimensions are $10 \times 20 \mathrm{~mm}$ and tube length of $1.2 \mathrm{~m}$. The riser to riser distance is $0.1 \mathrm{~m}$, and each tube has an equal right and left fin length of $40 \mathrm{~mm}$. These tubes are connected with two headers of rectangular cross sectional area one at each end to collect or distribute water from and into the risers, and from collector's outlet and inlet. The joints between the headers and risers ends are welded by using brass alloy.

A mat painted copper sheet is used as an absorbing plate of $1.20 \times 0.9 \mathrm{~m}$ and of $1.9 \mathrm{~mm}$ thickness. This sheet is welded to the risers by brass alloy, the structure is good insulated with a fire wool coating of 70 mm thickness. 

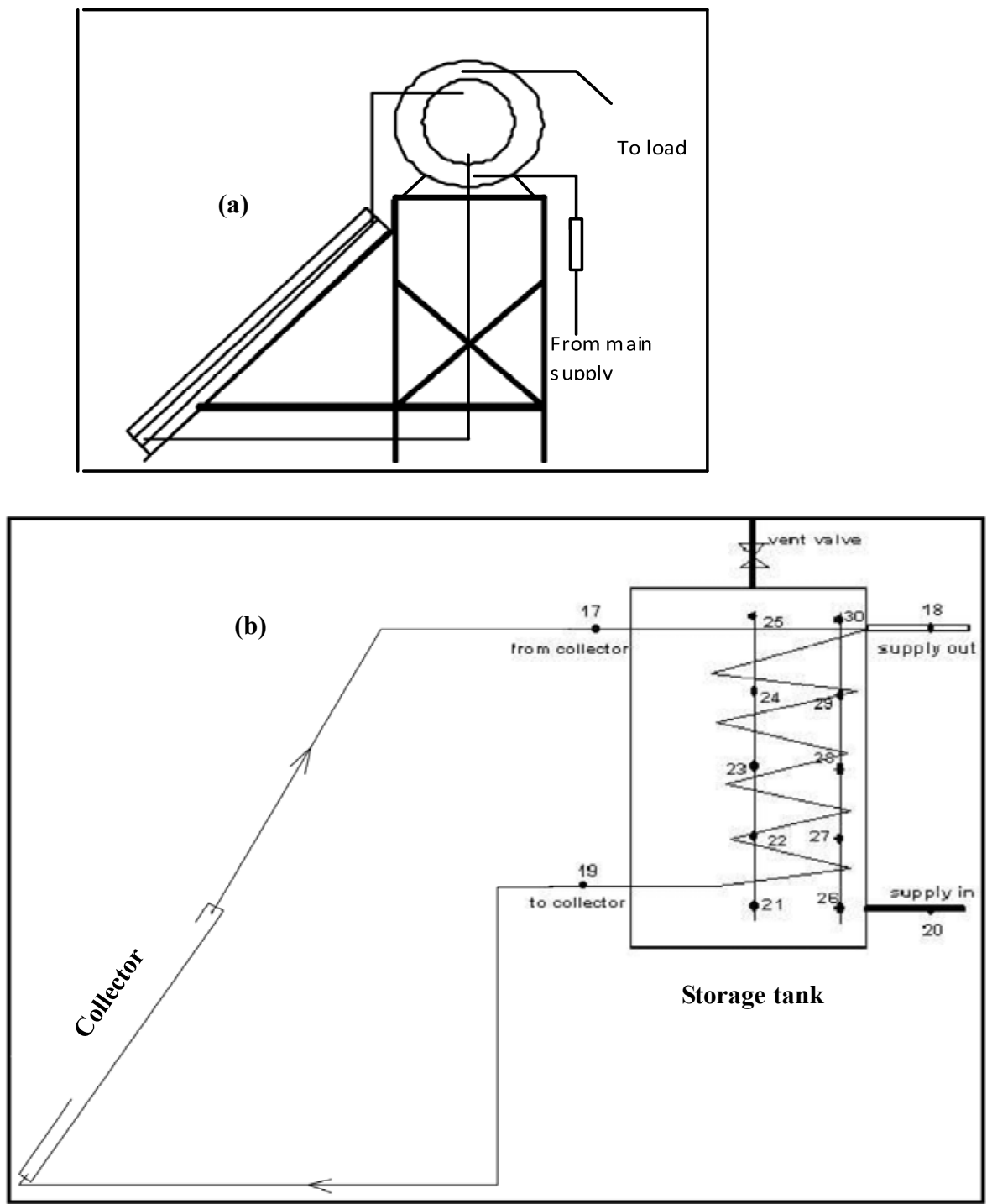

Figure 1. Close loop themosyphon solar water heater, the storage tank is a) Two concentric cylinders b) Helical coiled tube in cylindrical tank

\subsection{Conventional Flat Plate Solar Collector}

A conventional flat plate collector without accelerator plate is designed identical to an accelerated flat plate collector, and it consists of nine equal spaced parallel copper rectangular cross sectional area pipes of inlet and outlet with equal hydraulic diameters of 20 $\mathrm{mm}$. In addition, the inlet and outlet cross sections dimensions are $20 \times 20 \mathrm{~mm}$ and $1.20 \mathrm{~m}$ length, and the riser to riser distance is $0.1 \mathrm{~m}$. Each tube has an equal fin length to right and left of $40 \mathrm{~mm}$, and these tubes are connected with two headers of rectangular cross sectional area. The risers are welded to the header using brass alloy. A copper sheet is used as an absorbing plate of $1.20 \times 0.9 \mathrm{~m}$ and of $1.9 \mathrm{~mm}$ thickness. This sheet is welded to the risers using a brass alloy, the pipes are supported from the bottom by a galvanized plate of $2 \mathrm{~mm}$ thickness. The structure is wellinsulated with a glass wall coating of $70 \mathrm{~mm}$ thickness.
The collector box frame is manufactured from a 2 $\mathrm{mm}$ thickness galvanized sheet formed as a box, and the collectors are connected to their containers by screws. The collectors are well-insulated by using glass wool insulation of $70 \mathrm{~mm}$ thickness from the back of the collectors and $50 \mathrm{~mm}$ thickness from the perimeter of the collectors. A glass panel of $4 \mathrm{~mm}$ thickness is used as a transparent cover for the collector with area of $1.25 \times 0.95 \mathrm{~m}^{2}$. The glass cover lies on the collector frame in a small channel $25 \mathrm{~mm}$ wide, and is fixed by using a black silicon. A piece of rubber tape is fixed between the glass and channel to prevent air leakages. The cover-absorbing plate spacing is $70 \mathrm{~mm}$.

\subsection{Storage Tanks}

\subsubsection{Shell and Tube Storage Tank}

Two concentric horizontal cylinders form the stor- 


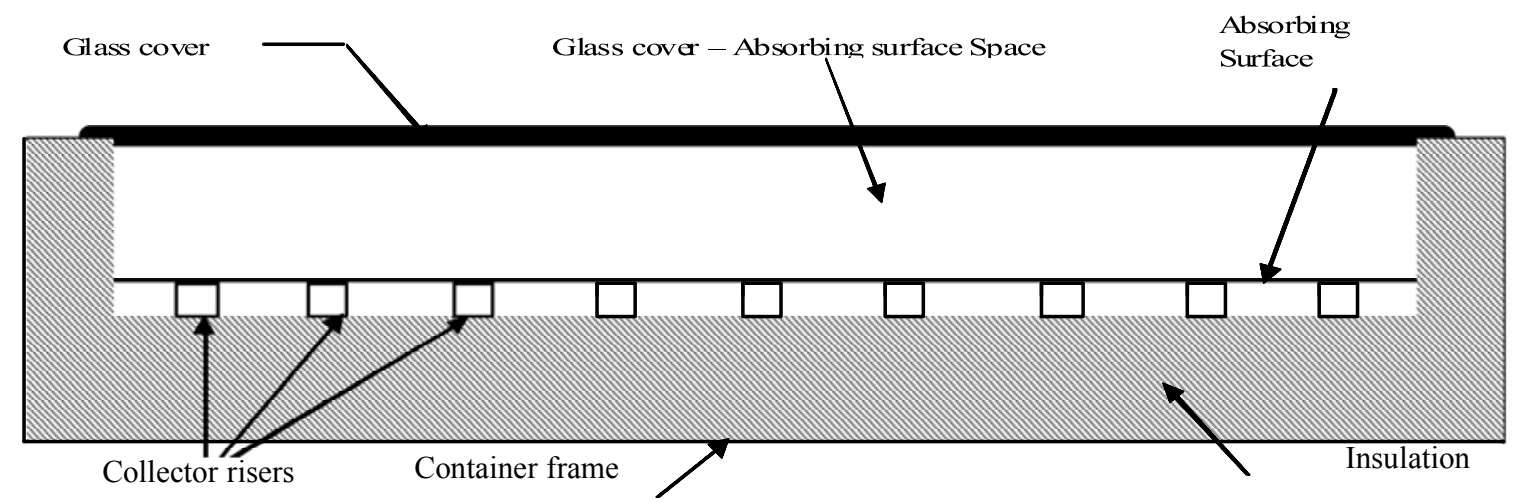

a) Collector cross sectional view

b) Accelerated riser (front view)

c) Conventional riser (front view)

Figure 2. Configuration of manufactured flat plate collector

age tank made from a galvanized plate of $2 \mathrm{~mm}$ thickness. The internal cylinder has an inner diameter of $375 \mathrm{~mm}, 1 \mathrm{~m}$ length and capacity of $110 \mathrm{~L}$. The outer cylinder has an internal diameter of $470 \mathrm{~mm}$ and a length of $1.2 \mathrm{~m}$, forming an annular space of $90 \mathrm{~L}$. The internal cylinder is used for the closed-loop water (energy carrier) while the annular space between internal and external cylinders is used for loading water (domestic use water). Each cylinder has two holes to form inlet and outlet ports. The tank is well insulated by a glass wool insulator of $70 \mathrm{~mm}$ thickness, and the storage tank can be oriented horizontally or vertically as required.

\subsubsection{Coiled Tube In Shell}

Another storage tank manufactured by (Karima et al. 2011) is used in the present work. This tank (made from a galvanized sheet) is of $125 \mathrm{~L}$ volume, $1 \mathrm{~m}$ height and $0.4 \mathrm{~m}$ diameter. A coiled tube is inserted inside in the tank which in turn is well insulated with glass wool of $10 \mathrm{~mm}$ thickness. A $0.6 \mathrm{~m}$ high coiled tube is made by winding a copper tube of $9.5 \mathrm{~mm}$ diameter around a cylinder to form twelve turns of $0.25 \mathrm{~m}$ outside coil diameter. A spacer was placed between each two consecutive coil turns to ensure a uniform pitch along the coil, which measured $0.05 \mathrm{~m}$.

\subsection{Temperature Measurement}

One hundred and five (105) calibrated thermo- couples (Type T Copper and Constantan) are used to measure the temperature at various points of water tubes, water storage tanks, inlet and outlet of collectors, inlet and outlet of the withdrawal water, ambient and glass cover, as shown in Fig. 3. The entire number of thermocouples are joined to Digital thermometer reader (Autonics-T4WM/ K(CA) 0-1200). The ambient temperature is measured by a using a mercury in glass- thermometer.

\subsection{Flow Rate Measurement}

The mass flow rate of the thermosyphon circulation flat plate collectors is so small tht only the laser flow meter can detect the flow which in not available, so a transparent tube of $250 \mathrm{~mm}$ length and $10 \mathrm{~mm}$ diameter is connected between collector outlet and storage tank inlet. An ink injection is used to calculate the circulation rate by injecting ink and measuring the time required to pass the $250 \mathrm{~mm}$ distance using stopwatch to compute fluid velocity. The water load flow rate is measured by using a flow meter of $2-22 \mathrm{~L} / \mathrm{min}$. range.

\subsection{Test Procedure}

The thermosyphon circulation solar water flat plate collectors were connected as a closed loop (indirect) system. The experiments were carried out from January to March 2009. Before each test, the following preparations were made, the closed collector loop 


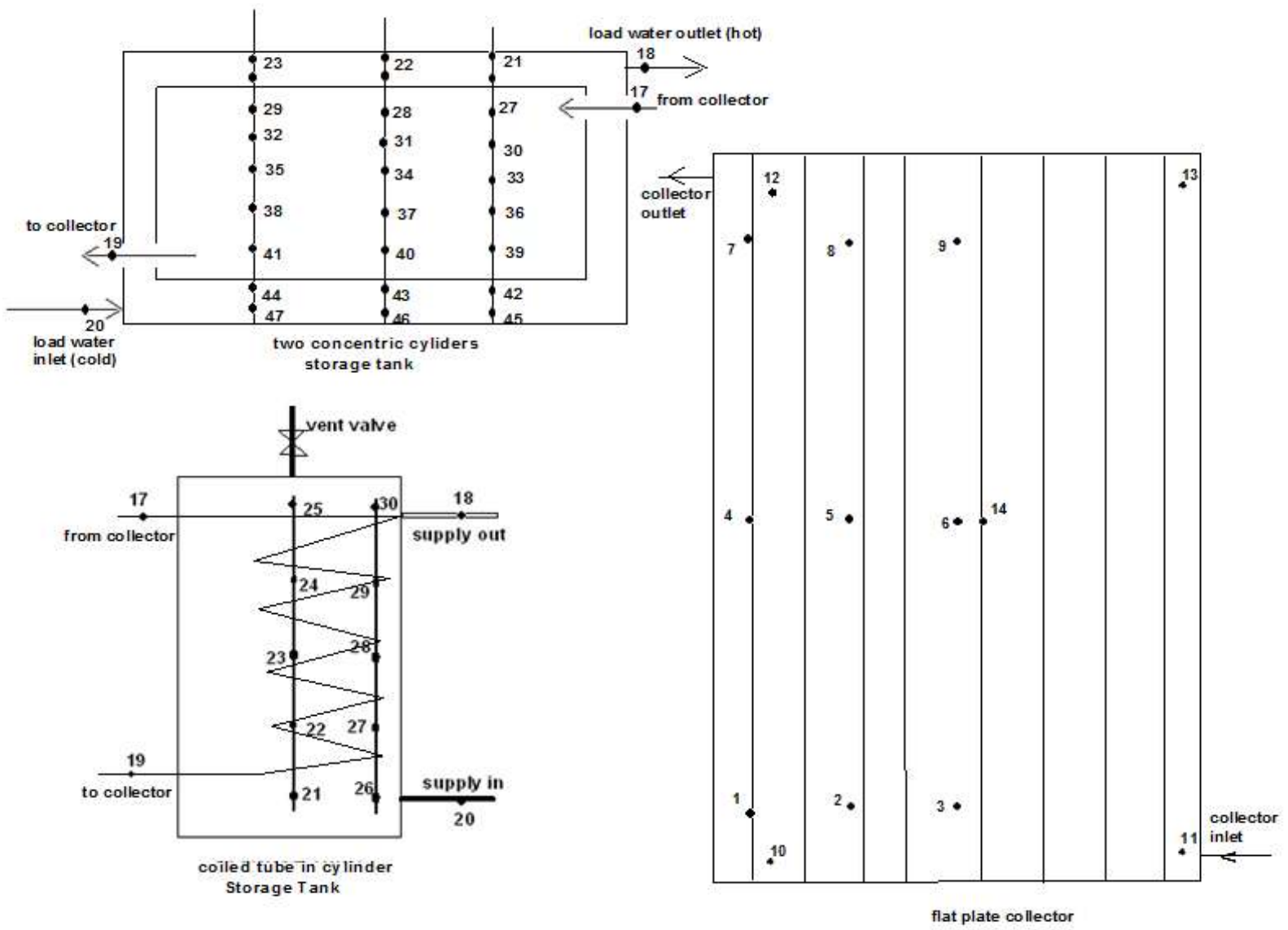

Figure 3. Locations of temperature measurements

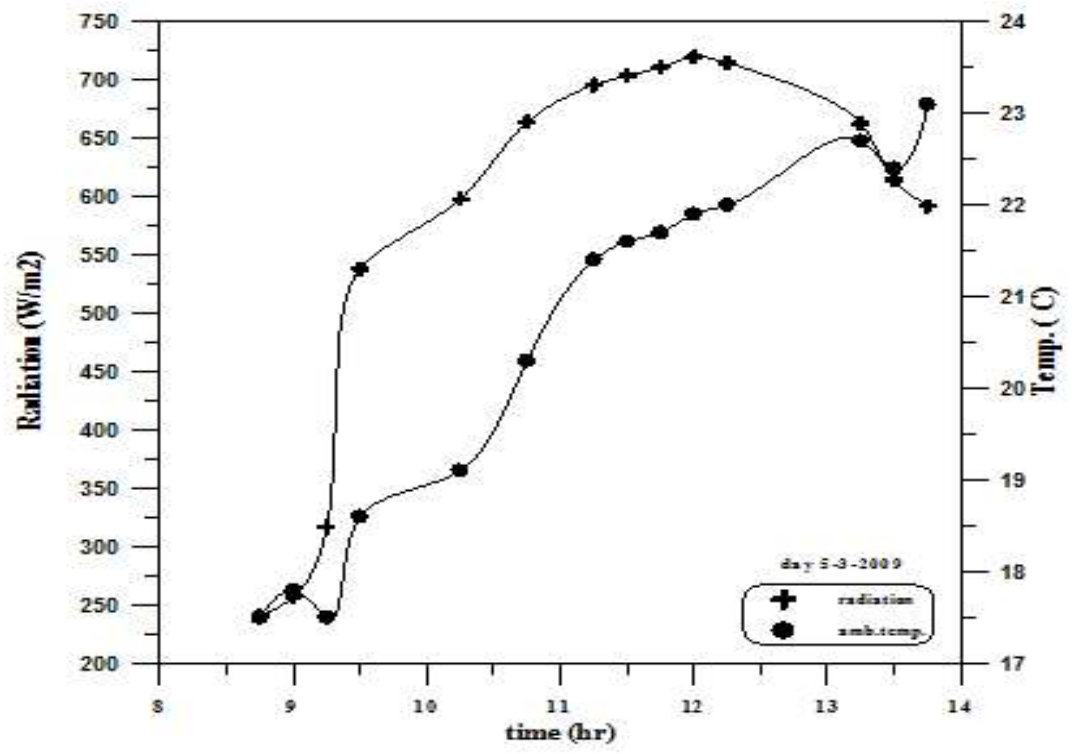

Figure 4. Solar radiation on horizontal surface and ambient temperature (5/3/2009 at $33.3^{\circ} \mathrm{N}$. Baghdad)

was filled with water, the glass cover is cleaned thoroughly and the measurements and apparatus were checked. Then the storage tanks were filled with water and readings were taken each half hour from sunrise to sunset. The newly-designed system was tested side by side with the conventional type.
The test was conducted from sunrise to sunset for five different mass flow rates of load water withdrawal profiles. These profiles were: continuous load of 2.6 $\mathrm{L} / \mathrm{min}$, the profile (II) shown in Fig. 7 which is equivalent to daily consumption of single storage tank vol- 

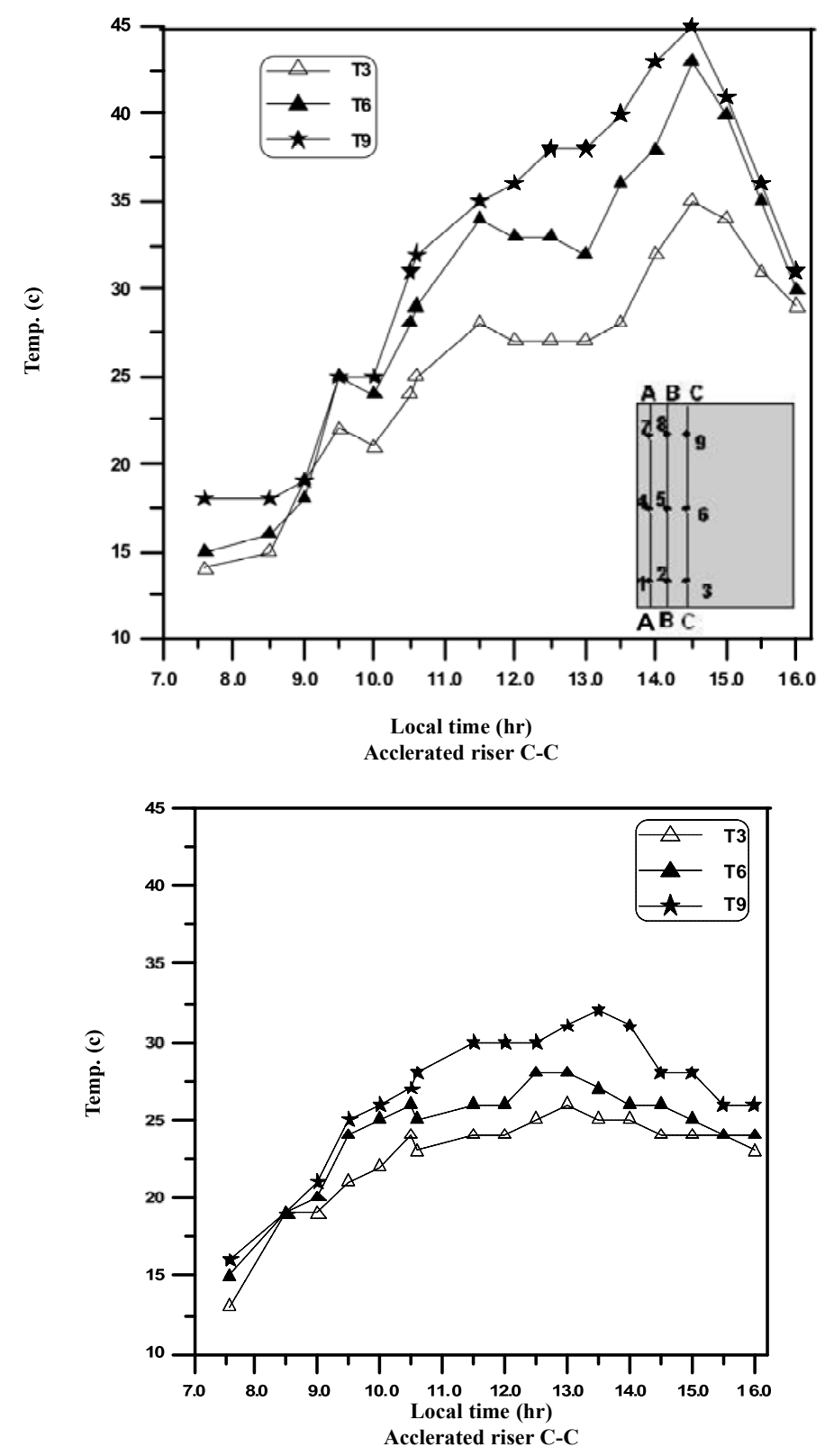

Figure 5. Water temperature distribution along risers

ume, emptying the storage tank twice a day and finally emptying it once a day. This propose is to test the effect of storage tank orientation (horizontally and vertically) on the thermal performance and study the effect of using a coiled tube for collector closed-loop instead of cylindrical tank. In all the above cases all temperature measurements, flow rate (circulation rate and loop flow rate), wind- speed are recorded.

\section{Results and Discussions}

Figure 4 shows the ambient temperature (measured (every 15 minutes) and solar radiation for the 24 hours of 27-1-2009 on the solar collector, which is obtained from the Ministry of Science and Technology Solar Center in Baghdad. It is clear that the peak solar radiation was between hours of 11 to 13 . The peak ambient temperature was $19{ }^{\circ} \mathrm{C}$.

Figure 5 shows the hourly water temperature rise along a selected riser $\mathrm{C}-\mathrm{C}$ for the accelerated conventional type. It is clear that the temperature rises with time as water proceed along the risers length, but lesser temperature values are indicated for the conventional type since the accelerated riser occupies less water volume at the cross section especially at the riser on the upper part. Figure $6(\mathrm{a} \& \mathrm{~b})$ shows a comparison 

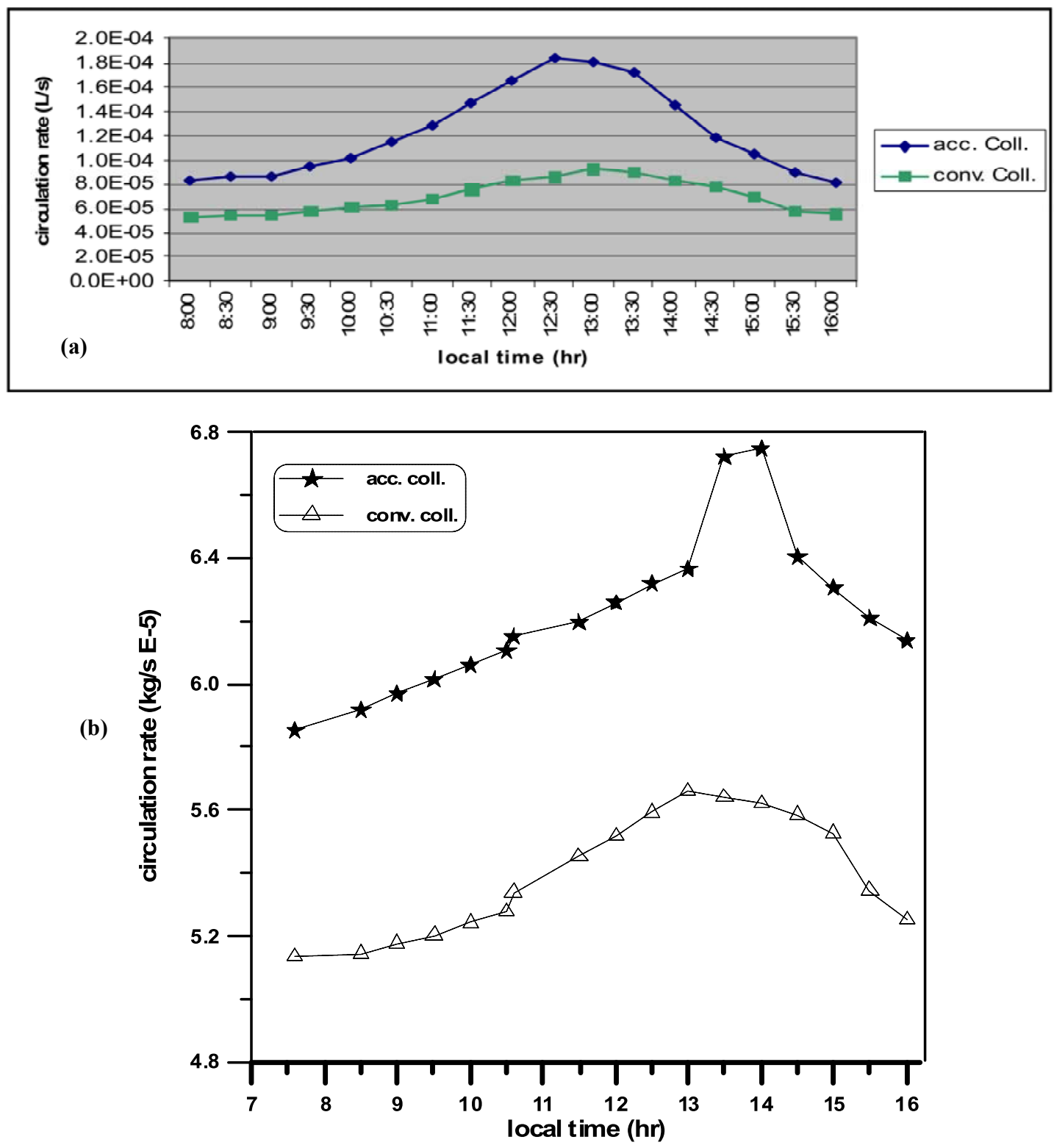

Figure 6. The thermosyphon circulate rate in the collector $\left(33.3^{\circ} \mathrm{N}\right.$. Baghdad) a) Profile I, b) Profile II

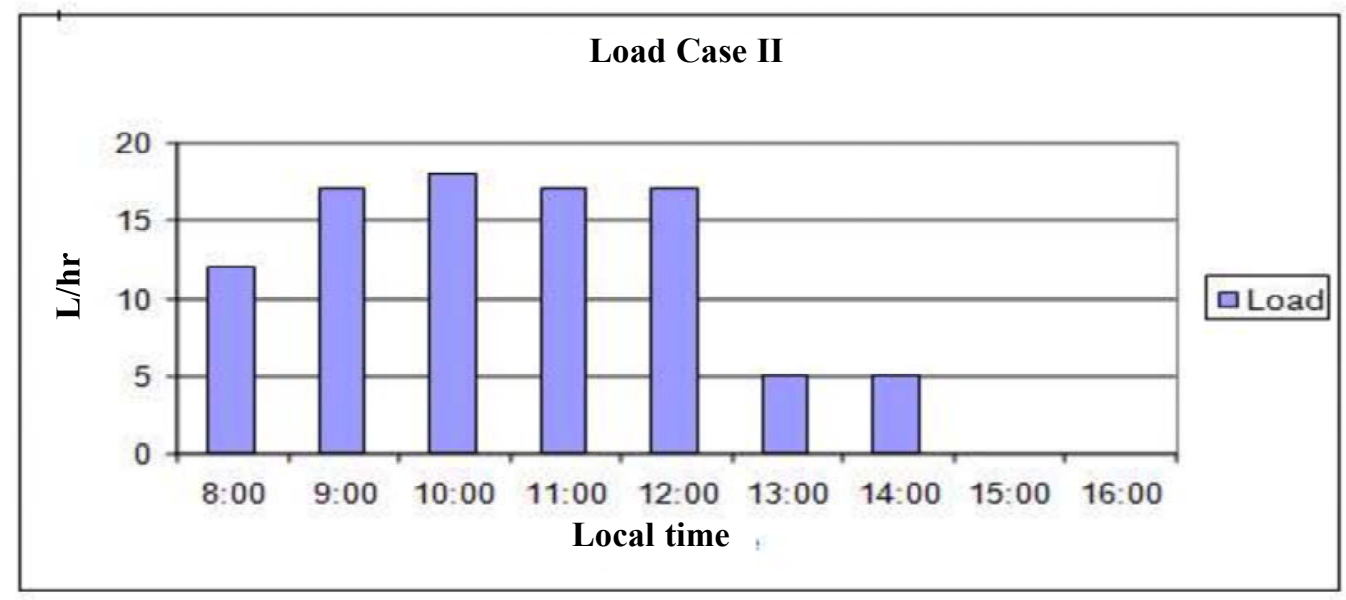

Figure 7. Water withdrawal profile (Case II) 


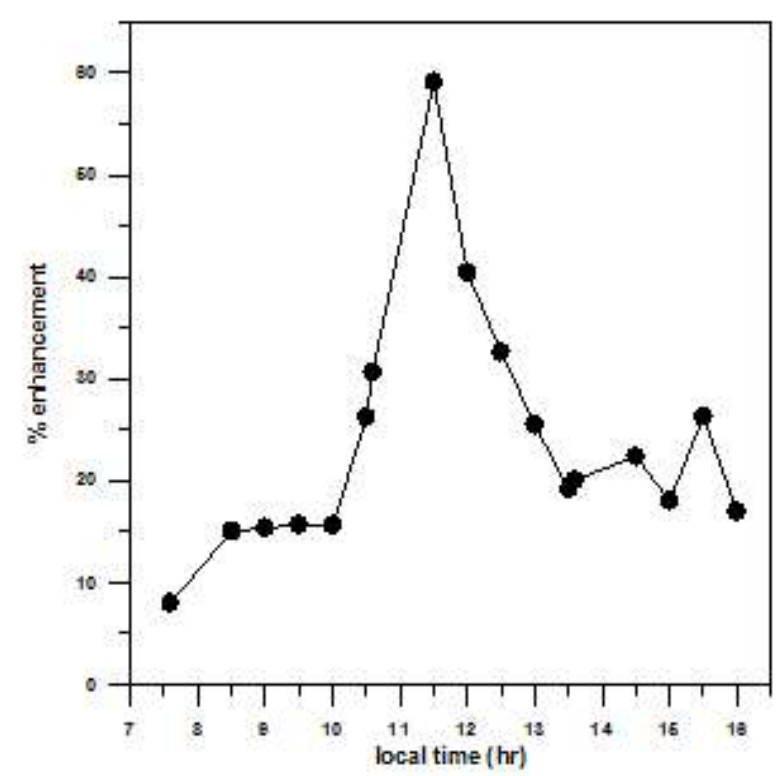

Figure 8. Percentage enhancement in absorbed heat when using accelerated collector compared with conventional collector (Horizontal tank case II)

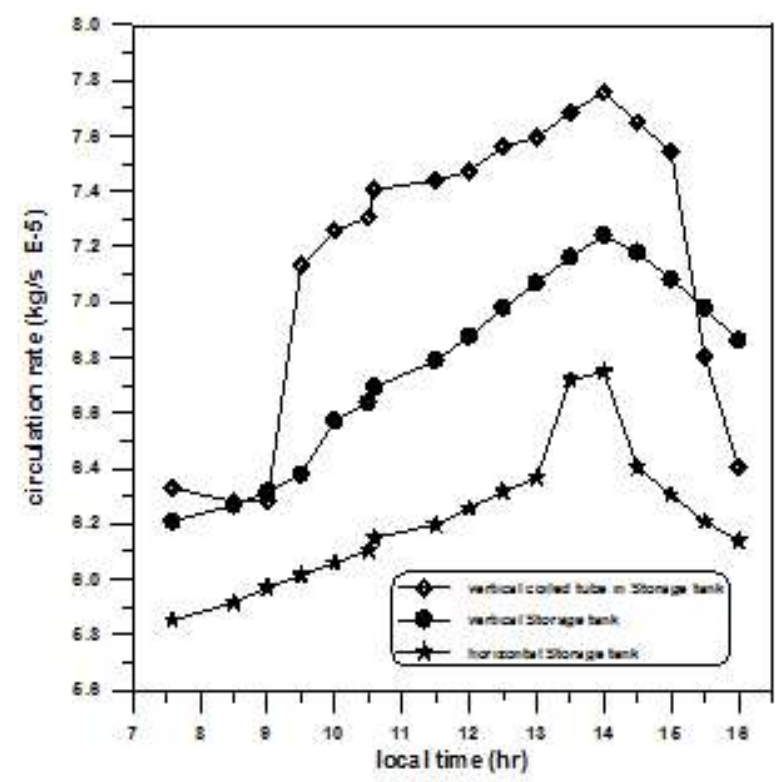

Figure 10. Effect of tank orientation and type on thermosyphon circulation rate (Profile II)

of the circulation rate between the accelerated and conventional flat plate for load profile I and load profile II shown in Fig. 7 respectively. A significant increase in the circulation rate is recorded from the first hour of day to the last hour, due to the new design criteria of the risers (converging cross sectional area). The maximum increase was at solar noon, and was due to exposing the same area to the same incident solar

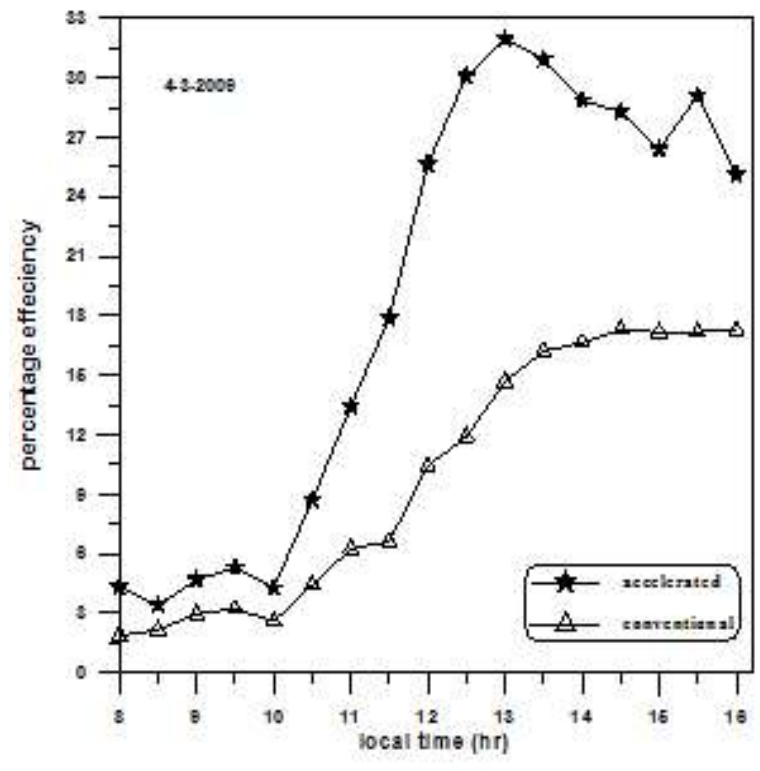

Figure 9. The instantaneous efficiency of the conventional and (accelerated collector for load Profile II)

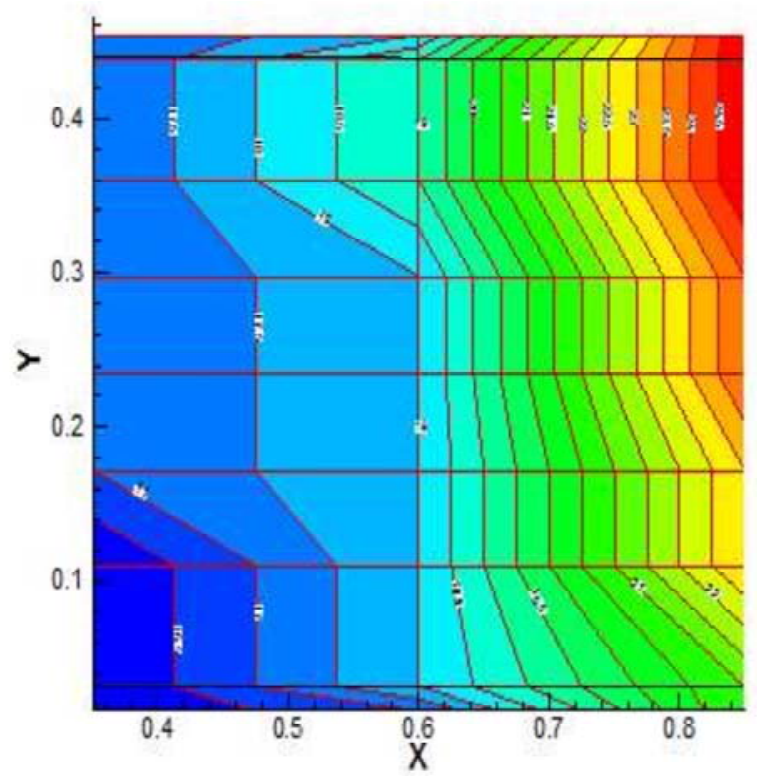

Figure 11. Stratification in shell and tube horizontal storage tank (accelerated collector load Profile I)

radiation. However, the water content in the converging risers was less than that in the straight riser so the temperatures increased and its density was lighter, resulting in it rising faster. Figure 8 shows the percentage enhancement in absorbed heat when using an accelerated collector compared to a conventional collector (horizontal tank case II). The useful energy enhancement was calculated using Eq. (3). The maxi- 


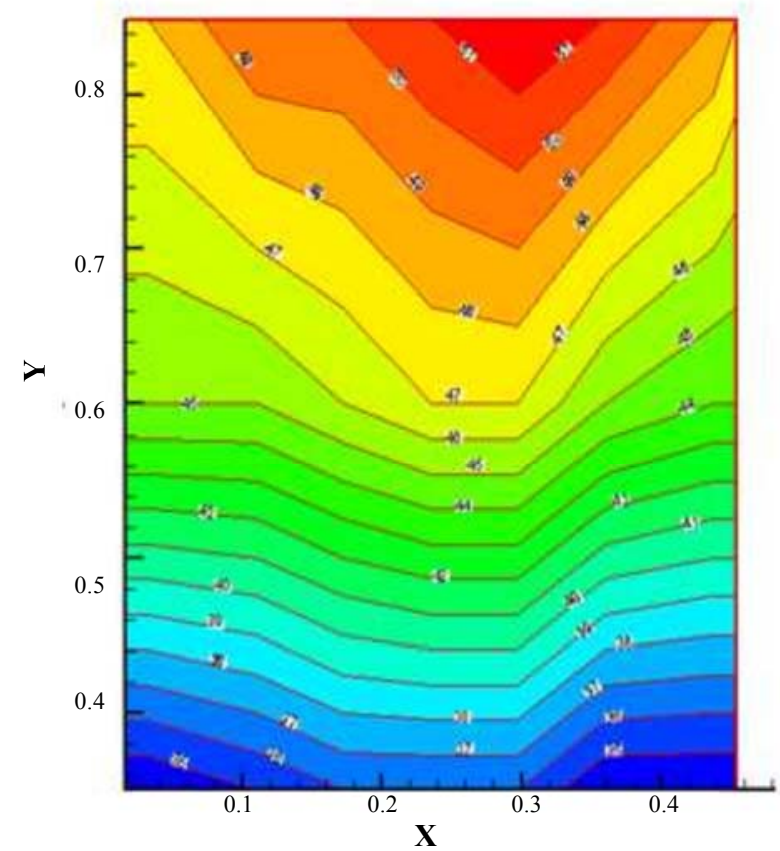

Figure 12. Stratification in two concentric cylinders vertical orientation (accelerated collector for no load)

mum enhancement was $60 \%$ at solar noon and the minimum was measured at the day's run hour. Thus the new design recorded an instantaneous efficiency of $32.8 \%$, while the conventional type indicated $17 \%$ as a maximum value, as shown in Fig. 9. Figure 10 shows that the vertical orientation of the storage tank enhances the circulation rate, and the coiled tube in cylinder has a much more effective design than the two concentric cylinders. Figure 11 shows the horizontal stratification in the concentric cylinders storage tank when connected to the accelerated collector. The upper right corner shows the hottest region (inlet of hot water from collector and exit of hot load water $\mathrm{T}=24.5{ }^{\circ} \mathrm{C}$ ), while the lower left corner is the coldest region exit of cold water to the collector and the inlet of cold load water $\mathrm{T}=16.5^{\circ} \mathrm{C}$ ). Figure 12 shows the vertical stratification in the two concentric cylinders for no load where the maximum temperature indicated at the upper surface (inlet of collector hot water and exit of load hot water $\mathrm{T}_{\max }=51{ }^{\circ} \mathrm{C}$ ). Figure 13 shows the vertical stratification in the coiled tube in the cylindrical storage tank for load profile II, where the maximum temperature indicated at the upper surface (inlet of collector hot water) and exit of load hot water $\mathrm{T}_{\max }$ $=37.1{ }^{\circ} \mathrm{C}$.

\section{Conclusions}

This research shows that the system thermal behavior

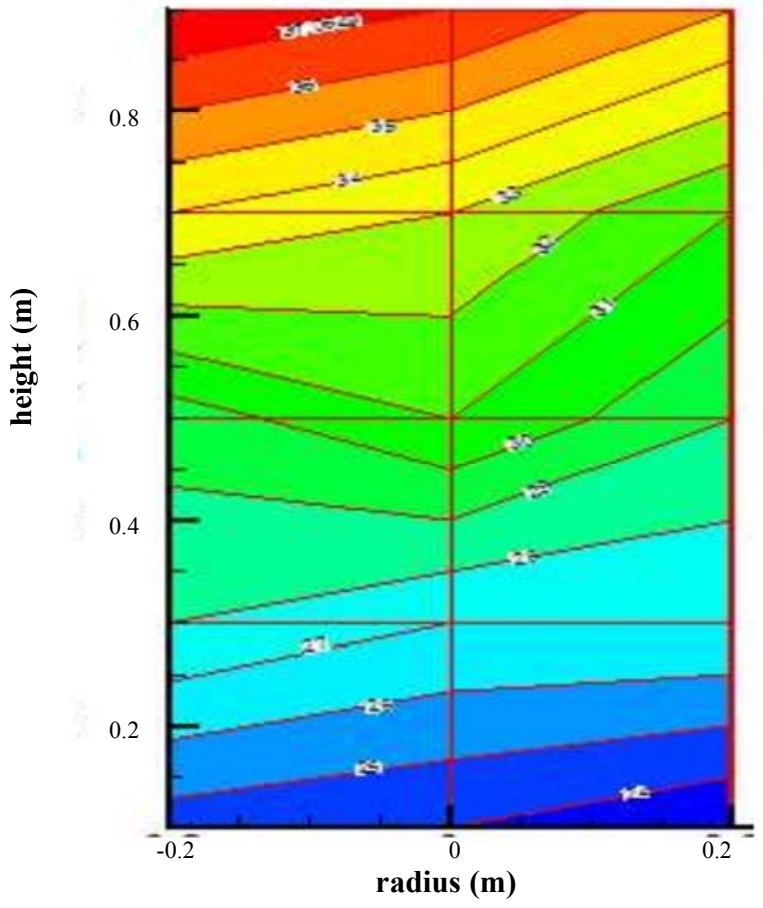

Figure 13. Stratification in coiled tube in cylinder vertical storage tank (accelerated plate load II)

is sensitive to any component and can be enhanced further by modifying the design parameters and material selections. The following concluding remarks can be made, based upon this work.

* The stratification obtained in the storage tank is significantly affected by the collector inlet temperature.

* The stratification obtained in the storage tank relates proportionately to the type of load rate (or load withdrawal pattern).

* Increasing the flow rate of the load decreases the stratification in the storage tank

* The effectiveness of the storage tank (shell and coiled tube) reaches approximately $78 \%$ for $(450$ $\mathrm{mL} / \mathrm{min}$ ) load flow rate.

* Using a car radiator instead of the coiled tube enhances the thermal performance of the storage tank.

* Using an accelerated (converging) riser will enhance the thermal performance of the thermosyphonic solar collector because it will increase the circulation rate.

\section{References}

Duffie JA, Beckman WA (1974), Solar energy thermal process. John Wiley \& Sons Inc. New York.

Karima AE, Mustafa FF, Sahar M (2011), Solar 
water heater with shell and helical coiled tube heat exchanger as a storage tank. J. of Engineering 17(5):1213-1222.

Khalifa AN (1999), Thermal performance of locally made flat plate solar collectors used as part of a domestic hot water system. Energy Conversion \& Management 40:1825-1833.

Klett DE, Goswami DY, Saad MT (1984), Thermal performance of submerged coil heat exchangers used in solar energy storage tanks. J. of Solar Energy Engineering 106:373-375.

Lunde P (1980), Solar thermal engineering, space heating and hot water systems. John Wiley \& Sons Inc. New York.
Myrna D (1997), High performance in low flow solar domestic hot water systems. MSc. Thesis Mechanical Engineering University of WisconsinMadison.

Shokouhmand H, Salimpour MR, AkhavanBehabadi MA (2008), Experimental investigation of shell and coiled tube heat exchangers using wilson plots. Int. Communications In Heat And Mass Transfer 35:84-92.

Soteris K (2009), Thermal performance, economic and environmental life cycle analysis of thermosyphon solar water heaters. Solar Energy 83:39-48. 